\title{
The Implementation of Problem Based Learning Strategies to Improve Learning Outcomes in Introduction Economic Subject to the Student of Universitas Negeri Medan
}

\author{
Thamrin \\ Economic education Department \\ Universitas Negeri Medan \\ Medan, Indonesia \\ Coreesponding Email:thamrinpjt@gmail.com
}

\author{
Abdul Hasan Saragih \\ Educational Technology Department \\ Universitas Negeri Medan \\ Medan, Indonesia
}

\author{
Abdul Muin Sibuea \\ Educational Technology Department \\ Universitas Negeri Medan \\ Medan, Indonesia
}

\begin{abstract}
Problem-based learning strategy (PBL) is used to improve student learning outcomes in the Unimed economic education study program that is less satisfying. The purpose of this study was to determine differences in learning outcomes Introduction to economics between groups of students taught with $P B L$ strategies and groups of students taught with direct learning strategies. This study used an experimental quasi method with a sample of 90 people. Data collection is done by conducting tests. The results of the study with $t$ test, $\alpha 0.05$ stated that the introductory learning outcomes of the group of students who were taught with PBL learning strategies were higher than the group of students who were taught with direct learning strategies.
\end{abstract}

Keywords-Problem-based learning strategi, direct learning strategy, learning outcomes.

\section{INTRODUCTION}

Professional lecturers must understand about learning strategy, be able to choose a learning strategy that is in accordance with the characteristics of students and the type of learning material to be taught. Learning strategies are needed for lecturers and students as a systematic guide and guideline in the implementation of the learning process that can facilitate students to take part in learning process.

Learning strategies cover various aspects in sorting and organizing learning materials and making decisions about how to present learning materials and learning activities. Learning activities include: presentation of learning materials, examples, exercises and giving feedback. In order to those objectives can be achieved optimally, all learning activities must be planned and regulated by considering the characteristics of students, time, resources, media and learning process situation.
Dick and Carey explained that the instructional strategy describes how the designer uses the information from analyzing what is to be taught in a plan for connecting learners with the instructions being developed [1]. Based on this opinion it can be understood that learning strategies play a role in learning processes and outcomes. The magnitude of the role of learning strategies towards learning processes and outcomes can be seen in the learning process of introduction to economics courses in economic education department. This course is a basic course that aims at competent students to identify and analyze the behavior of individual economic actors, explain the process of equilibrium price, apply it in daily life both as a consumer and producer and analyze the market.

Based on the results of interviews with lecturers who teach introduction to economics courses and students of economic education department, information was obtained that learning had always centered on lecturers with direct learning strategies. Learning begins with a lecture, gives an example and ends with exercise. Such learning is felt by students is very monotonous and does not train students to think creatively and analytically and solve problems. Students feel bored and bored quickly because learning is not varied, less communicative between students and ultimately students are less interested in introducing economic learning.

Introduction to economics learning is also not meaningful, so students are unable to link the theories with the real conditions that occur in society. On the other hand, one of the characteristics of introductory economic learning is relevance, which means that in introduction to economics learning it is expected that there will be a connection between what is learned in class and what is done on campus and what happens in the community. 
This is in line with the explanation of the least popular disciplines of indicated economics in terms of student feedback on teaching, and noted by the 1990s, while many other disciplines have introduced much more variety and interactivity into teaching, economics as per embedded to lectures, supported by limited audiovisual input, with textbooks and possibly workbooks as the staple [2]. Learning conditions as stated above have implications for students' economic learning outcomes that are less satisfactory.

The data of the students' economic learning outcomes shows that only $5.70 \%$ of the students obtained the maximum score (A), $11.42 \%$ got B score, while those with $\mathrm{C}$ scores were $48.57 \%$ and those who did not graduate with E score were $34.28 \%$ (Data source List of the final score of economic education study department 2014).

From these data it can be seen that the results of introduction to economics learning are still not satisfactory. There are about $34.28 \%$ of students who still get less grades. Based on these conditions, an effort is needed to improve the ability of students in introductory economics courses through the selection of learning strategies that are in accordance with the characteristics of students and learning materials, namely PBL strategies.

PBL was first introduced in the world of education in the 1960 's by Barrows at McMaster University, Canada in the medical field It was then expanded to other medical schools around the world, such as Michigan State University in the United States, Maastricht University in the Netherlands, and Newcastle University in Australia. Consequently, PBL is then expanded in other fields such as engineering, economics, science, language, history and education. Currently, problembased learning approach and the use of real cases or PBL has been one of the very popular curriculum innovations in education [3].

The classical definition of problem-based learning is: "the learning that results from the process of working towards the understanding of a resolution of a problem[4]. The students' tutor guided them to work problems[5]

This is in line with the statement that "PBL is an instructional strategy. That is, it is an instructional solution designed to improve learning by requiring students to learn content while solving problems [6].

PBL was developed in response to the problems and limitations of traditional teaching approaches. It is an encouraging way to learn, as students work with problems that are challenging and observed in their real life. Students realize that the learning needed to solve and understand existing problems is valuable[7].

PBL strategy has some characteristics; 1). learning is student-centered, 2) earning occurs in small student groups, 3) tutors are facilitators or guides, 4) problems form the organizing focus and stimulus for learning, 5) problems are a vehicle for the development of problem- solving skills. 6)new information is attained through self-directed learning[8]. Many supporters of PBL presume that this teaching method is very motivating for students.

\section{METHODOLOGY}

The purpose of this study was to determine differences in economic introductory learning outcomes between groups of students taught with PBL learning strategies and groups of students taught with direct learning strategies. This research was conducted in Unimed Economic Education department. This research is a quasi-experimental study. The population in this study were all students of semester I economic education department 2016/2017 academic year. Samples were taken by random sampling of two classes. The experimental class consisted of 45 experimental students and 45 control class student.

Data collection techniques used in this study are tests of introductory economic learning outcomes. The learning process takes place during eight meetings, each meeting in the experimental class begins with a discussion of the problem on the worksheet to be completed, while the control class is taught by direct learning strategies. The instrument used to obtain introductory economic learning data and use of learning outcomes tests in the cognitive domain. The instrument used has been tested for validity and reliability.

Analysis used to process the data in this study is t test, using SPSS 17.0 for Windows program after an analysis prerequisite test conducted.

\section{RESULT AND DISCUSSION}

Before the data is analyzed, the normality and homogeneity tests are carried out. Description of students' economic learning outcomes data can be seen in table 1 .

TABLE.1. Introduction To Economic Students Learning Outcomes

\begin{tabular}{|l|c|c|}
\hline \multicolumn{1}{|c|}{ Statistic } & $\begin{array}{c}\text { PBL } \\
\text { (Experimental } \\
\text { class) }\end{array}$ & $\begin{array}{c}\text { Direct Learning } \\
\text { (Control Class) }\end{array}$ \\
\hline Mean & 76,37 & 71,80 \\
\hline Minimum & 55,86 & 55,86 \\
\hline Maximum & 94,08 & 85,26 \\
\hline Std.Deviation & 10,89 & 7,612 \\
\hline
\end{tabular}

Table 1 shows that the average introduction to economic learning outcomes of experimental class students by applying PBL strategies have an average score of 76.37, higher than the average control class with an average score of 71.80 . The highest score in the experimental class is 94.08 and the control class is 85.26 .

Furthermore, the average comparison of student learning outcomes between groups of students taught with PBL and direct learning can be seen in Figure.1. 


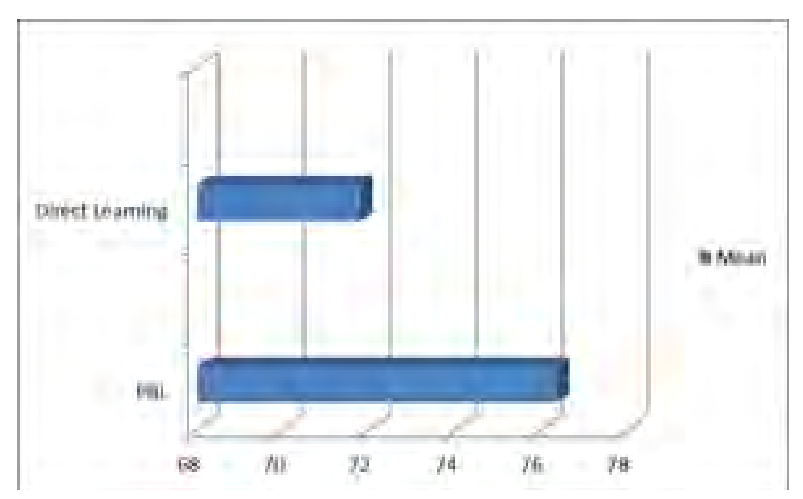

Fig1. Comparison Of Average Student Learning Outcomes Based On Learning Strategies.

Figure 1. shows the average economic introductory learning outcomes of student groups taught with a higher PBL strategy than student groups taught with direct learning strategies

Hypothesis test results of the influence of the PBL strategies implementation on introduction to economic student learning outcomes are presented in Table 2.

TABEL.2. Analysis Results Summary Of Pbl Strategy On The Results Of Introduction Of Economic Students

\begin{tabular}{|l|l|l|l|l|l|l|l|}
\hline \multicolumn{2}{|c|}{} & \multicolumn{6}{|c|}{ T-test for Equality of Means } \\
\cline { 3 - 7 } & t & Df & Sig & $\begin{array}{l}\text { Mean } \\
\text { Differ } \\
\text { rence }\end{array}$ & $\begin{array}{l}\text { 95\% } \\
\text { Confidence } \\
\text { Interval }\end{array}$ \\
\cline { 3 - 7 } & & & & & & Lower & $\begin{array}{l}\text { Upp } \\
\text { er }\end{array}$ \\
\hline $\begin{array}{l}\text { Learni } \\
\text { ng } \\
\text { outco } \\
\text { mes }\end{array}$ & $\begin{array}{l}\text { Equa } \\
\text { Varian } \\
\text { ces } \\
\text { not } \\
\text { assu }\end{array}$ & $\begin{array}{l}2, \\
31\end{array}$ & 78,9 & 0,023 & 4,57 & .645 & 8.50 \\
\hline
\end{tabular}

From Table 2 can be seen the results of the calculation of the analysis of differences in the results of introductory economic learning groups of students taught using problem-based learning strategies and direct learning strategies at the value of $\mathrm{Sig}=0.023$ with a significance level of $5 \%$. This means that if the probability significance ( $p$-value) is $<0.05$, the null hypothesis (Ho) is in the rejection area because of the probability significance (p-value) $<\alpha(0.05)$. Calculations on student economic learning outcomes, Ho was rejected so that Ha was accepted on economic introductory learning outcomes between the control group with direct learning and the experimental group with problem-based learning was significantly different so that the application of problem-based learning had an effect on student economic learning outcomes.

This explains that PBL strategies are better for improving students' abilities in introduction to economics courses compared to direct learning strategies. The results of this study are in line with the research which states that the integration of PBL in economic education programs can improve academic achievement, develop inter-personal and intra-personal communication skills, learn how to express opinions. This is an important characteristic for life in the modern world. Based on these indications, the results of this study can be a reference and guidelines for the implementation and effectiveness of PBL approaches in studies related to student academic achievement in economic education department. [9].

Students who taught with PBL strategies are more motivated to learn than their peers who study with lectures. Furthermore, it was explained that students who learn with PBL strategies are more likely to take responsibility for their own learning than those who learn with conventional strategies. [10]

Futhermore, it can be explained that PBL can improve the critical thinking of dental students, teaching them to analyze and solve real problems, which prepares them for their future careers. This remarkable depelop ment in teaching approaches has improved the effectiveness of teaching in dental education institutes [11].

PBL strategy in the practice of implementing education, familiarizing students with problems and practicing to overcome these problems which aim to equip students with knowledge, skills and experience that can be flexibly applied in everyday life. Learning students with problem-based use all the knowledge, abilities and skills possessed in learning, so that the learning outcomes obtained will be optimal.

Students actively seek, find, process, synthesize and conclude information in accordance with the problems solved, so that the knowledge and skills acquired are not memorized, but are built and developed in accordance with the potential of each student.

Tan also explained that the problem-based learning of students' thinking abilities is truly optimized through a systematic group or team work process, so that students can empower, hone, test and develop their thinking skills continuously [12].

This research is in line with research that explains that the results for this study show that there is generally a good reception to the method by students and that the method effectively develops communication skills, teamwork and problem solving [13].

Also, this research is in line with previous research that states the survey results also indicated that a PBL approach provided significant benefits to the students in their presentation skills, teamwork. In addition, student responses to the open-ended questions revealed that PBL was an acceptable way of learning [14].

PBL methods improve the effectiveness of student learning, enhance student performance in challenging tasks, and promote better knowledge retention. PBL appears to have strong effects on learning and accom- plishment compared with other approaches in which learning is not based on problem solving[15]. 


\section{CONCLUSION AND SUGGESTION}

\section{A. Conclusion}

Based on the results of the study and discussion can be summarized as follows:

1. There are significant differences in introduction to economic learning outcomes between groups of students taught with problem-based learning strategies with economic introductory learning outcomes of groups of students taught with direct learning strategies.

2. The application of problem-based learning strategies has a significant effect on improving the learning outcomes of introduction to economics students.

\section{B. Suggestion}

1. Based on the average introduction to economic learning outcomes of groups of students taught with problem-based learning strategies higher than the student groups taught with direct learning strategies, it is suggested that inroduction to economic lecturers can be advised to apply this problem-based learning strategy in this subject..

2. Because this introduction to economic course is a basic course that aims to enable students to analyze economic phenomena that exist in society, it is suggested that lecturers can take real problems that occur in the community to be applied in learning process..

\section{REFERENCES}

[1] Dick, W, Carey, L, and Carey, James O, 2015. The Systematic Design of Instruction ,USA: Pearson, p.3.

[2] Fry, H., Ketteridge, S., \& Marshall, S. (Eds.). 2008. A handbook for teaching and learning in higher education: Enhancing academic practice. Routledge.p. 3

[3] Surif, J., Ibrahimb, N. H., \& Mokhtarc, M. 2013. Implementation of problem based learning in higher education institutions and its impact on students' learning. PBL Across Cultures, p.66.

[4] Barrett, T., \& Moore, S. 2010. New approaches to problem-based learning: Revitalising your practice in higher education. Routledge, p. 4

[5] O’Grady, G., Yew, E. H., Goh, K. P., \& Schmidt, H. G. 2012. One-Day, One-Problem.

[6] Jonassen, D.H.,2011, Learning to Solve Problems, A Handbook for Designing Problem Solving Learning Environment. New York: Routledge, p.154.

[7] Barrows, H.,.2002, Is it truly possible to have such a thing as PBL? Distance Educ. 23 (1), p. 119-122

[8] Alrahlah, A. 2016. How effective the problem-based learning (PBL) in dental education. A critical review. The Saudi dental journal, 28(4), p. 158.

[9] Manaf, A., Aziah, N., \& Wan-Hussin, W. N. 2011. Application of Problem Based Learning (PBL) in a course on financial accounting principles. Malaysian Journal of Learning and Instruction, Vol. 8 , 201, p.21

[10] Allen, D.E., Donham, R.S., Bernhardt, S.A., 2011, "Problem-based learning. In: New Directions for Teaching and Learning”, vol 128,, pp. 21-29

[11] Achuonye, K. A, 2010, A comparative study of problem-based and lecture-based learning in secondary school students' motivation to learn science. International journal of science and technology Education Research, 1(6), 126-131.

[12] Tan, O. S. 2003. Problem-based learning innovation: Using problems to power learning in the 21 st century. Thomson Learning Asia.
[13] Manaf, Ishak and Hussin, "Application of Problem Based Learning (PBL) in a Course Financial Accounting Principles", Malaysian Journal of Learning and Instruction, Vol. 8 , 201, p.21

[14] Allen, D.E., Donham, R.S., Bernhardt, S.A.,2011, "Problem-based learning. In: New Directions for Teaching and Learning”, vol 128, pp. 21-29

[15]Yalmanci.GÜRBÜZOĞLU,Sibel. Yalmanci, İbrahim.A, 2013, The Effect of Multiple Intelligence Theory Based Teaching On Students' Achievment and Retention Of Knowledge. International Journal on New Trends in Education and Their Implications, Vol. 4 Issue: 3 Article: 04 .pp. 27-36. 